\title{
КЛИНИЧЕСКИЕ ИССЛЕДОВАНИЯ
}

УДК 616-053.31-02:[618.1-022:579.887]-056.27

DOI 10.17816/pmi3565-9

\section{ОСОБЕННОСТИ АДАПТАЦИОННЫХ РЕАКЦИЙ И СОСТОЯНИЯ НОВОРОЖДЕННЫХ В ЗАВИСИМОСТИ ОТ СТЕПЕНИ КОЛОНИЗАЦИИ UR. UREALYTICUM ГЕНИТАЛИЙ РОЖЕНИЦ}

Т.А. Мельникова ${ }^{1 *}$, М.М. Падруль ${ }^{1}$, Э.С. Горович ${ }^{1}$, Г.И. Работникова ${ }^{2}$

${ }^{1}$ Пермский государственный медицинский университет им. академика Е.А. Вагнера,

${ }^{2}$ Городской консультативно-диагностический чентр Медико-санитарной части № 9

им. М.А. Тверье, г. Пермь, Россия

\section{CHARACTERISTICS OF ADAPTIVE RESPONSES AND STATUS OF NEWBORNS DEPENDING ON DEGREE OF PARTURIENT GENITAL COLONIZATION WITH UR. UREALYTICUM}

\author{
T.A. Melnikova ${ }^{1 *}$, M.M. Padrul', E.S. Gorovits ${ }^{1}$, G.I. Rabotnikova ${ }^{2}$ \\ ${ }^{1}$ Academician Ye.A. Vagner Perm State Medical University, \\ ${ }^{2}$ City Consultative-Diagnostic Center of Hospital № 9 named after M.A. Tverie, Perm, Russian Federation
}

Цель. Изучение особенностей состояния новорожденных в зависимости от уровня колонизации гениталий рожениц Ur. urealyticum.

Материалы и методы. Изучены особенности состояния новорожденных у 112 родильниц, которые по результатам повторного микробиологического обследования на уреаплазмоз в сроке 30-34 недели беременности были разделены на три группы. Первая (38 человек) с отрицательными результатами ПЦР и бактериологии, во II группу (риска) вошли 39 женщин, инфицированных Ur. urealyticum до $10^{4} \mathrm{KOE} / \mathrm{мл}$ и в ПЦР $5 \times 10^{4}$ ДНК копий на мл. Третью составили 35 беременных женщин - бакпосев менее $10^{4} \mathrm{KOE} / \mathrm{Mл.}$ Группа сравнения - 40 беременных, не инфицированных уреаплазмами при первичном обследовании.

Результаты. У новорожденных родильниц группы риска цифровые значения показателя по шкале Апгар на 1-й и 5-й минутах были статистически значимо ниже, чем у детей от матерей других групп. В этой же группе достоверно чаще регистрировали рождение недоношенных и с гипотрофией детей, также синдром задержки развития плода. Перинатальную энцефалопатию выявляли у 50,0 \% новорожденных. При выписке из роддома почти половина детей этой группы не набрали первоначально требуемую массу тела, а в остальных группах таких детей было в 2,0-2,5 раза больше.

( Мельникова Т.А., Падруль М.М., Горовиц Э.С., Работникова Г.И., 2018

тел. +7 (342) 2171031

e-mail: melnikova.ta1111@mail.ru

[Мельникова Т.А. ("контактное лицо) - аспирант кафедры акушерства и гинекологии; Падруль М.М. - доктор медицинских наук, профессор, заведующий кафедрой акушерства и гинекологии; Горовиц Э.С. - доктор медицинских наук, профессор, заведующий кафедрой микробиологии и вирусологии с курсом КЛд; Работникова Г.И. кандидат медицинских наук, врач акушер-гинеколог]. 
Выводы. Дети, рожденные от матерей, инфицированных Ur. urealyticum в высоких этиологически значимых титрах, отличаются снижением адаптационных реакций, о чем свидетельствуют показатели шкалы Апгар и замедленный набор массы тела после рождения. Высокий уровень колонизации половых путей рожениц Ur. urealyticum негативно влияет на состояние здоровья новорожденных. Низкие этиологически незначимые титры Ur. urealyticum у матерей практически не влияют на состояние здоровья новорожденных.

Ключевые слова. Уреаплазмоз, беременность, новорожденные, осложнения.

Aim. To study the characteristic features of newborn status depending on the level of parturient genital colonization with Ur. urealyticum.

Materials and methods. The characteristic features of newborns' status were studied in 112 puerperas, who by the results of repeated microbiological examination for ureaplasmosis, in the period of 30-34 weeks of pregnancy were divided into 3 groups: group I included 38 persons with negative results of PCR and bacteriology; group II (risk) joined 39 women, infected with Ur. urealyticum to $10^{4} \mathrm{CFU} / \mathrm{ml}$ and PCR $5 \cdot 10^{4} \mathrm{DNA}$ copies per $\mathrm{ml}$; and group III - 35 pregnant women with bacterial inoculation less than $10^{4} \mathrm{CFU} / \mathrm{ml}$. The comparison group - 40 pregnant women, uninfected with ureaplasmas when examined for the first time.

Results. In newborn children from puerperas of risk group, Apgar scores at 1 and 5 minutes were statistically significantly lower, than in children, born from mothers of the other groups. In this group, birth of premature newborns and those with hypotrophy as well as newborns with fetal development retardation syndrome were registered significantly more often. Perinatal encephalopathy was detected in $50.0 \%$ of newborns. When discharged from maternal home, nearly a half of infants from this group had no the initially required body mass, but in the other groups there were 2-2.5 times more such newborns.

Conclusions. Newborns from mothers infected with Ur. Urealyticum in high, etiologically significant titers, are characterized by decrease in adaptive responses that is proved by Apgar scores and by retarded body mass growth after birth. High level of parturient genital colonization with Ur. urealyticum has a negative effect on the newborns' health status. Low, etiologically insignificant Ur. urealyticum titers in mothers practically don't influence the newborns' health status.

Key words. Ureaplasmosis, pregnancy, newborns, complications.

\section{ВВЕДЕНИЕ}

Несмотря на снижение уровня младенческой смертности, этот показатель в Российской Федерации остается достаточно высоким $[2,5,8,11,13]$. Так, в 2017 г. он составил 5,6 на 1000 живорожденных. Существенный вклад в эти показатели вносят инфекционные заболевания беременных и прежде всего инфекции, передающиеся половым путем, в частности уреаплазмоз. Ранее мы сообщали о негативном влиянии уреаплазменной инфекции (в случаях обнаружения высоких концентраций Ur. urealyticum) на течение беременности и родов [9]. В настоящей работе представлены данные об особенностях адаптационных реакций и состояния новорож- денных, родившихся от матерей, инфицированных Ur. urealyticum.

Цель исследования - изучение особенностей состояния новорожденных в зависимости от уровня колонизации гениталий рожениц Ur. urealyticum.

\section{МАТЕРИАЛЫ И МЕТОДЫ ИССЛЕДОВАНИЯ}

Под наблюдением находилось 112 беременных, по данным микробиологического обследования, выполненного на 20-24-й неделе беременности, инфицированных Ur. urealyticum, с различной степенью колонизации генитального тракта. На основании результатов повторного комплексного об- 
следования, проведенного на 30-34-й неделе беременности с использованием бактериологического анализа и количественного варианта ПЦР-диагностики, они были разделены на три группы. Первую составили 38 женщин с отрицательными результатами обследования на уреаплазмоз в обоих тестах. У них удалось добиться полной элиминации возбудителя после традиционного курса специфического лечения. Во вторую группу (группу риска) вошли 39 беременных с высоким титром Ur. urealyticum (более $5 \cdot 10^{4}$ ДНК-копий на мл) по данным ПЦР. Они не получали соответствующего лечения, поскольку при первичном бактериологическом обследовании на уреаплазмоз Ur. urealyticum высевали в этиологически незначимых титpax (менее $10^{4}$ КОЕ на мл). В третью группу вошли 35 беременных с низкой концентрацией уреаплазм по данным повторного комплексного обследования. Условно здоровые беременные (40 человек) составили группу сравнения. Изучены адаптационные реакции и состояние новорожденных у указанных групп рожениц.

Для статистической обработки использовали компьютерную программу Statistica 6,0. Для оценки достоверности величин применяли $t$-критерий Стьюдента, статистически значимыми считали различия при $p<0,05$.

\section{РЕЗУЛЬТАТЫ И ИХ ОБСУЖДЕНИЕ}

Состояние гипоксии у новорожденных не было выявлено ни в одном случае (табл. 1). Как следует из представленных данных, на 1й минуте самые высокие значения показателя по шкале Апгар выявлены у новорожденных от условно здоровых матерей. Достаточно высокими эти показатели были у новорожденных от матерей I и III групп, в то же время у детей от матерей с высокой концентрацией Ur. urealyticum данный показатель статистически значимо был ниже.

Аналогичную закономерность наблюдали и на 5-й минуте жизни ребенка, при этом адаптационные реакци у всех новорожденных нарастали, соответственно, увеличивались цифровые значения показателя по шкале Апгар. И вновь эти значения были существеннее в группе условно здоровых родильниц, а наименышие - у новорожденных от матерей второй группы.

Установлена прямая умеренная корреляционная зависимость между значениями показателя и наличием преждевременных родов $(r=0,493 ; p=0,0012)$, а также гипотрофии $(r=0,504 ; p=0,0001)$. При этом значения показателя по шкале Апгар на 1-й и 5-й минутах практически во всех случаях коррелировали друг с другом. Следовательно, у детей, родившихся от матерей, инфицированных Ur. urealyticum в высоких титpax, адаптационные механизмы были менее выражены, чем у новорожденных от матерей других групп. При этом не было выявлено существенных различий этих показателей у новорожденных от матерей всех остальных групп. Результаты оценки состояния новорожденных суммированы в табл. 2.

Из приведенных данных следует, что в группе инфицированных рожениц с титром Ur. urealyticum по ПЦР от 5,0 $10^{4}$ ДНК-копий статистически значимо чаще регистрировали недоношенных детей и детей с гипотрофией. При этом у данных матерей было больше детей с массой тела менее 3000 г, родившихся доношенными (синдром задержки развития плода) - 15,38 \% случаев против 5,1\% группе сравнения ( $p=0,0507)$. У новорожденных от матерей II группы также чаще, почти в половине случаев, встречалась 
Таблица 1

\section{Оценка состояния новорожденных по шкале Апгар в зависимости от степени колонизации половых путей матери Ur. urealyticum}

\begin{tabular}{|c|c|c|c|c|c|c|c|c|c|c|}
\hline \multirow{2}{*}{$\begin{array}{c}\text { Время } \\
\text { оценки, мин }\end{array}$} & \multicolumn{10}{|c|}{ Цифровые значения показателя у детей от матерей различных групп } \\
\hline & I & II & III & IV & $p_{1}$ & $p_{2}$ & $p_{3}$ & $p_{4}$ & $p_{5}$ & $p_{6}$ \\
\hline 1 & $7,49 \pm 0,22$ & $7,10 \pm 0,24$ & $7,29 \pm 0,26$ & $7,93 \pm 0,08$ & 0,0001 & 0,0234 & 0,0001 & 0,3830 & 0,0008 & 0,0001 \\
\hline 5 & $8,40 \pm 0,18$ & $8,08 \pm 0,18$ & $8,21 \pm 0,21$ & $8,83 \pm 0,12$ & 0,0001 & 0,0169 & 0,0001 & 0,2942 & 0,0001 & 0,0001 \\
\hline
\end{tabular}

При мечание: здесь и в табл. $2: p_{1}, p_{2}, p_{3}, p_{4}, p_{5}$ и $p_{6}-$ достоверность отличий показателей между II и I группами; II и III; II и IV; I и III; I и IV; III и IV группами соответственно.

Таблица 2

\section{Особенности состояния здоровья новорожденных}

\begin{tabular}{|c|c|c|c|c|c|c|c|c|c|c|}
\hline \multirow{2}{*}{$\begin{array}{c}\text { Патологические } \\
\text { состояния } \\
\text { новорожденных }\end{array}$} & \multicolumn{4}{|c|}{$\begin{array}{c}\text { Количество случаев в группе } \\
\text { родильниц }(\% \pm 2 m)\end{array}$} & \multirow{2}{*}{$p_{1}$} & \multirow{2}{*}{$p_{2}$} & \multirow{2}{*}{$p_{3}$} & \multirow{2}{*}{$p_{4}$} & \multirow[t]{2}{*}{$p_{5}$} & \multirow{2}{*}{$p_{6}$} \\
\hline & $\mathrm{I}(n=38)$ & II $(n=39)$ & III $(n=35)$ & IV $(n=40)$ & & & & & & \\
\hline Недоношенность & $5,3 \pm 5,3$ & $20,5 \pm 12,7$ & $8,6 \pm 8,6$ & $5,0 \pm 5,0$ & 0,0467 & 0,0001 & 0,0410 & 0,8081 & 0,9840 & 0,5101 \\
\hline Гипотрофия & $10,5 \pm 9,8$ & $15,4 \pm 11,3$ & $5,7 \pm 5,7$ & $5,0 \pm 5,0$ & 0,5323 & 0,0001 & 0,1326 & 0,7238 & 0,6746 & 0,1667 \\
\hline $\begin{array}{l}\text { Конъюгационная } \\
\text { желтуха }\end{array}$ & $18,4 \pm 12,3$ & $23,1 \pm 13,2$ & $20,0 \pm 13,3$ & $17,5 \pm 11,8$ & 0,6202 & 0,8201 & 0,5435 & 0,9077 & 0,9442 & 0,7372 \\
\hline $\begin{array}{l}\text { Перинатальная } \\
\text { энцефалопатия }\end{array}$ & $36,8 \pm 15,5$ & $48,7 \pm 15,7$ & $40,0 \pm 16,2$ & $35,0 \pm 14,8$ & 0,0001 & 0,0001 & 0,0001 & 0,9692 & 0,7339 & 0,0094 \\
\hline $\begin{array}{l}\text { Гнойно-септичес- } \\
\text { кие заболевания }\end{array}$ & $2,6 \pm 2,6$ & $5,1 \pm 5,1$ & $2,9 \pm 2,9$ & 0 & 0,5759 & 0,8667 & 0,1506 & 0,9868 & 0,3080 & 0,2881 \\
\hline
\end{tabular}

перинатальная энцефалопатия - 48,7 \%. Гнойно-септические заболевания у новорожденных от условно здоровых матерей (IV группа) и женщин, получавших лечение (I группа), не выявили, тогда как во II и III группах были зарегистрированы соответственно два и один такой случай. Что касается конъюгационной желтухи, то частота встречаемости этой патологии у новорожденных практически не отличалась в сравниваемых группах родильниц.

В итоге здоровыми родились 71 \% детей от матерей IV группы и только 51,3 \% от родильниц в группе риска. В I группе родильниц, у которых после лечения удалось добиться эрадикации возбудителя, и в III группе (с низким уровнем колонизации генитального тракта Ur. urealyticum) количество таких новорожденных соответственно составило 66,3 и 64,8 \%. Как следствие, к мо- менту выписки из роддома почти половина новорожденных (49,8 \%) от матерей II группы не набрали первоначально требуемую массу тела, в то время как в остальных сравниваемых группах таких детей было в 2,0-2,5 раза больше. Это свидетельствует о лучшей адаптации новорожденных при отсутствии инфекционного процесса, обусловленного Ur. urealyticum у их матерей.

\section{Выводы}

1. Дети, рожденные от матерей, инфицированных Ur. urealyticum в высоких этиологически значимых титрах, отличаются снижением адаптационных реакций, о чем свидетельствуют показатели шкалы Апгар и замедленный набор массы тела после рождения.

2. Инфекционный процесс, связанный с высокой степенью колонизации половых пу- 
тей рожениц Ur. Urealyticum, негативно влияет на состояние здоровья новорожденных, что проявляется в развитии постгипоксических, дезадаптационных синдромов (задержка развития плода, перинатальная энцефалопатия), а также рождением недоношенных детей с низкой массой тела.

3. Низкие этиологически незначимые титры Ur. urealyticum, диагностируемые у матерей, практически не влияют на состояние здоровья новорожденных.

\section{БИБЛИОГРАФИЧЕСКИЙ СПИСОК}

1. Базина М.И. Беременность и роды при внутриутробных инфекциях: автореф. дис. ... канд. мед. наук. Омск 2000; 21.

2. Боровкова Е.И., Сидорова И.С. Взаимодействие возбудителей инфекции с организмом беременной как фактор риска внутриутробного инфицирования плода. Акушерство и гинекология 2005; 2: 20-24.

3. Бубнова Н.И., Сорокина 3.Х. Значение морфологического исследования последа в диагностике врожденных инфекций у новорожденных детей // Мать и дитя: III Российский форум. М. 2001; 546-547.

4. Буренина Н.А. Особенности патогенеза хронической плацентарной недостаточности у беременных с генитальной микоплазменной инфекцией: автореф. дис. ... канд. мед. наук. Н. Новгород 2005; 24.

5. Габидуллина Т.В., Тимошина Е.Л., Юръев С.Ю. Влияние урогенитальных инфекций на течение беременности и состояние плода и новорожденного. Бюллетень сибирской медицины 2002; 1: 84-88.

6. Газовская Л.А. Клиническое течение и лабораторная диагностика внутриутробных инфекций (хламидийной, микоплазменной, цитомегаловирусной и герпесви- русной) у новорожденных детей: дис. ... канд. мед. наук. М. 1997; 128.

7. Плацентарная недостаточность и инфекция. Под ред. В.И. Кулакова, Н.В. Орджоникидзе, В.Л. Тютюнника. М.: Медицина 2004; 494.

8. Лысенко К.А., Тютюнник В.Л. Перинатальные аспекты микоплазменной инфекции. Акушерство и гинекология 2007; 4: 8-11.

9. Мельникова Т.А., Падруль М.М., Горович Э.С., Работникова Г.И. Анализ течения беременности у женщин, инфицированных Ur. urealyticum, в зависимости от степени колонизации генитального тракта. Пермский медицинский журнал 2017; 34 (2): 26-30.

10. Никонов А.П. Внутриутробные инфекции - мифы и реальность. Сотрудничество во благо: материалы I Сибирского съезда акушеров-гинекологов, дерматовенерологов и урологов с междунар. участием. Новосибирск 2007; 50.

11. Пак К.О., Александров Ю.А., Копылова Н.А. Клинические и патогенетические аспекты поражений центральной нервной системы у детей с врожденным микоплазмозом. Материалы III съезда Рос. ассоц. перинатальной медицины. М. 2000; 249-250.

12. Пасхина И.Н., Орджоникидзе Н.В., Пономарева Л.П. Перинатальные инфекции и многоводие. Акушерство и гинекология 2004; 3: 8.

13. Dob K. Differential vaginal expression of interleukin-1 system cytokines in the presence of Mycoplasma bominis and Ureaplasma urealyticum in pregnant women. Infect Dis Obstet Gynecol 2004; 12 (2): 79-85.

14. Taylor-Robinson D., Furr P.M. Genital mycoplasma infections. Wien Klin Wochenschr 1997; 109 (14-15): 578-583.

Материал поступил в редакцию 12.10.2018 